\title{
EFEKTIVITAS MEDIA E-MODUL BERBASIS SCHOOLOGY
}

\author{
I Gede Fajar Wirganata ${ }^{1}$, Ketut Agustini ${ }^{2}$, \\ Gede Saindra Santyadiputra ${ }^{3}$ \\ Jurusan Pendidikan Teknik Informatika \\ Fakultas Teknik dan Kejuruan \\ Universitas Pendidikan Ganesha \\ Singaraja, Bali \\ e-mail: fajardenatha13@gmail.com ${ }^{1}$, ketutagustini@undiksha.ac.id $^{2}$, \\ gsaindras@undiksha.ac.id ${ }^{3}$
}

\begin{abstract}
Abstrak
Tujuan dari penelitian ini adalah : Untuk menghasilkan rancangan dan mengimplementasikan hasil rancangan Pengembangan Modul Personalized Learning pada Mata Pelajaran Jaringan Wireless Kelas XI di SMK TI Bali Global Singaraja, mengetahui respon siswa dan guru terhadap Modul Personalized Learning pada Mata Pelajaran Jaringan Wireless Kelas XI di SMK TI Bali Global Singaraja. metode yang digunakan dalam penelitian ini adalah penelitian dan pengembangan (Research and Development) dengan model pengembangan ADDIE. Untuk mengetahui respon guru dan siswa terhadap e-modul Jaringan Wireless diperoleh dengan menggunakan metode angket. Hasil penelitian menunjukkan bahwa: Hasil rancangan dan realisasi Modul Personalze Learning Pada Mata Pelajaran Jaringan Wireless kelas XI di SMK TI Bali Global Singaraja dinyatakan berhasil diterapkan berdasarkan beberapa uji yang dilakukan. Hasil analisis data respon guru menunjukkan bahwa, didapatkan rata-rata skor respon sebesar 42, jika dikonversikan ke dalam tabel penggolongan respon maka termasuk pada kategori positif. Sedangkan untuk respon siswa terhadap pengembangan emodul didapatkan rata-rata skor respon sebesar 60,52, jika dikonversikan ke dalam tabel penggolongan respon siswa termasuk pada kategori positif.
\end{abstract}

Kata kunci: Modul Personalized Learning, Model PjBL

\begin{abstract}
The aims of this research are: To produce the design and implement the result of the Personalized Learning Module Development Design on the Class XI Wireless Network Subjects in IT SMK Global Singaraja, to know the response of students and teachers to the Personalized Learning Module on the Subject of Wireless Class XI Network in IT SMK Bali Global Singaraja. the method used in this study is research and development (Research and Development) with the development model of ADDIE. To know the response of teacher and student to e-module of Wireless Network obtained by using questionnaire method. The results showed that: The results of the design and realization of the Personalze Learning Module on the Subject of Wireless Networking class XI at IT SMK Global Singaraja was declared successfully applied based on several tests conducted. The results of teacher response data analysis showed that, got the average score response of 42, if converted into the response classification table then included in the positive category. As for the students response to the development of emodules obtained average response score of 60.52, if converted into the table classification of student responses included in the positive category
\end{abstract}

Keywords : Modul Personalized Learning, Model PjBL 


\section{PENDAHULUAN}

Perubahan perkembangan teknologi memaksa untuk semua pihak beradaptasi dengan cepat salah satunya dibidang pendidikan, menurut UUD SISDIKNAS No.20 tahun 2003 menyebutkan bahwa: "pendidikan merupakan salah satu usaha yang dilakukan secara sadar dan terencana untuk mewujudkan suasana dan proses pembelajaran agar peserta didik secara aktif mampu mengembangkan potensi yang ada didalam dirinya untuk memiliki kekuatan spiritual keagamaan, kepribadian yang baik, pengendalian diri, berahlak mulia, kecerdasan, dan keterampilan yang diperlukan oleh dirinya dan masyarakat".

Salah satu media yang memenuhi kriteria sebagai media pembelajaran mandiri adalah modul elektronik. Modul elektronik Personalized Learning dapat didefinisikan sebagai sebuah proses pembelejaran yang disesuaikan dengan kemampuan dan kebutuhan setiap siswa yang berbeda-beda dengan menggunakan teknologi informasi dan bentuk penyajian bahan belajar mandiri yang disusun secara sistematis ke dalam unit pembelajaran terkecil untuk mencapai tujuan pembelajaran tertentu, yang disajikan dalam format elektronik yang setiap kegiatan pembelajaran di dalamnya dihubungkan dengan link - link sebagai navigasi yang membuat peserta didik menjadi interaktif dengan program, dilengkapi dengan penyajian video tutorial, animasi dan audio untuk memperkaya pengalaman belajar. Modul elektronik atau yang biasa disebut dengan e-modul merupakan inovasi terbaru dari modul cetak, sehingga modul elektronik ini dapat diakses dengan bantuan komputer yang sudah terintregrasi dengan perangkat lunak yang mendukung pengaksesan e-modul. Kelebihan e-modul personalized learning dibandingkan dengan modul cetak adalah sifatnya yang interaktif memudahkan dalam navigasi, dapat menampilkan atau memuat gambar, audio, video dan animasi serta dilengkapi tes formatif yang memungkinkan umpan balik otomatis dengan segera.

dan konsep pengelolaan pembelajaran sosial yang dikhususkan untuk membangun lingkungan belajar online yang aman untuk berbagi informasi serta fitur-fitur atau konten pendidikan baik berbentuk tulisan, file dan link yang dapat dibagikan baik guru maupun siswa. Maka dari itu dengan adanya Schoology siswa dapat belajar secara online, berkolaborasi dengan rekanrekan mereka dan dapat belajar secara mandiri sesuai dengan tujuan model pembelajaran project based learning, selain itu dengan menggunakan Schoology proses pembelajaran akan lebih interaktif, karena dengan adanya Schoology dapat menyisipkan suatu bahan ajar tidak hanya dalam bentuk teks saja, bisa dalam bentuk animasi, audio maupun video yang dapat membuat siswa menjadi lebih tertarik dalam mempelajarinya sesuai dengan kebutuhan mata pelajaran Jaringan Nirkabel. Adapun kelebihan dari Schoology diantaranya stay conneted, extend class time, manage on the go serta leverage iOS and android device.

(Agustini, 2013) Sejak beberapa tahun belakangan ini teknologi informasi dan komunikasi telah banyak digunakan dalam proses belajar mengajar, dengan satu tujuan mutu pendidikan akan selangkah lebih maju seiring dengan kemajuan teknologi. Sebaian besar siswa kelas XI TKJ menuturkan bahwa mereka perlu media pembelajaran dengan materi yang dipaparkan tidak hanya berupa teks namun juga berupa gambar dan video animasi 2 dimensi yang menggambarkan konsep dari meteri-materi yang masih berupa abstrak menjadi lebih konkret sehingga menghasilkan media pembelajaran yang valid, praktis dan efektif yang dapat meningkatkan mutu serta kualitas pembelajaran

Berdasarkan uraian di atas, maka tujuan utama dari penelitian ini adalah untuk mengembangkan bahan ajar Modul Personalizeed Learning pada Mata Pelajaran Jaringan Wireless Kelas XI di SMK TI Bali Global Singaraja. Yang di harapkan mampu menangani permasalahan yang di hadapi guru dan siswa dalam proses pembelajaran.

\section{KAJIAN TEORI}


A. Pemelajaran Personlized Learning

Istilah pembelajaran personal, atau personalisasi, mengacu pada beragam program pendidikan, pengalaman belajar, pendekatan instruksional, dan strategi dukungan akademis yang dimaksudkan untuk memenuhi kebutuhan pembelajaran, minat, aspirasi, atau latar belakang budaya masing-masing siswa yang berbeda. Pembelajaran yang dipersonalisasi pada umumnya dilihat sebagai alternatif pendekatan "satu ukuran sesuai untuk semua" pada sekolah dimana guru dapat memberikan semua siswa dalam kursus tertentu dengan jenis instruksi yang sama, tugas yang sama, dan penilaian yang sama dengan sedikit variasi atau modifikasi dari siswa ke siswa. Pembelajaran yang dipersonalisasi juga dapat disebut pembelajaran berpusat pada siswa, karena tujuan umumnya adalah untuk membuat pembelajaran individual memerlukan pertimbangan utama dalam keputusan pendidikan dan instruksional yang penting.

\section{Model Pembelajaran Project Based Learning}

Pembelajaran berbasis proyek adalah suatu model pembelajaran yang melibatkan suatu proyek dalam proses pembelajaran. Proyek yang dikerjakan oleh siswa dapat berupa proyek perseorangan atau kelompok dan dilaksanakan dalam jangka waktu tertentu secara kolaboratif, menghasilkan sebuah produk, yang hasilnya kemudian akan ditampilkan dan dipresentasikan. Pelaksanaan proyek dilakukan secara kolaboratif dan inovatif, unik, yang berfokus pada pemecahan masalah yang berhubungan dengan kehidupan siswa. Pembelajaran berbasis proyek merupakan bagian dari metode instruksional yang berpusat pada pebelajar.

\section{E-Modul (Modul Elektronik)}

Modul elektronik merupakan versi elektronik dari sebuah modul yang sudah dicetak yang dapat dibaca pada komputer dan dirancang dengan software yang diperlukan. E-modul merupakan alat atau sarana pembelajaran yang berisi materi, metode, batasan-batasan dan Author surnames go here 3 cara mengevaluasi yang dirancang secara sistematis dan menarik untuk mencapai kompetensi yang diharapkan sesuai dengan tingkat kompleksitasnya secara elektronik. Menurut (Gunadharma, 2011) modul elektronik dapat didefinisikan sebagai sebuah bentuk penyajian bahan belajar mandiri yang disusun secara sistematis ke dalam unit pembelajaran terkecil untuk mencapai tujuan pembelajaran tertentu, yang disajikan dalam format elektronik, dimana setiap kegiatan pembelajaran di dalamnya dihubungkan dengan link - link sebagai navigasi yang membuat peserta didik menjadi interaktif dengan program, dilengkapi dengan penyajian video tutorial, animasi dan audio untuk memperkaya pengalaman belajar. Modul elektronik yang dapat diakses oleh siswa mempunyai manfaat dan karakteristik yang berbeda beda. Jika ditinjau dari manfaatnya media elektronik sendiri dapat menjadikan proses pembelajaraan lebih menarik, interaktif, dapat dilakukan kapan dan dimana saja dapat meningkatkan kualitas pembelajaran (Cecep \& Bambang, 2013).

\section{Schoology}

Schoology merupakan salah satu platform inovatif yang dibangun berdasarkan inspirasi dari media sosial facebook dengan tujuan untuk kepentingan pendidikan. Platform ini dikembangkan pada tahun 2009 di New York. Platform Schoology dirancang Oleh Jeremy Friedman, Ryan Hwang dan Tim Trinidad. Komunitas Global Schoology diadopsi dari 12 juta orang di seluruh 130 negara di dunia. Schoology adalah Learning Managemen System (LMS) untuk K-12 sekolah, lembaga pendidikan tinggi, dan perusahaan yang memungkinkan pengguna untuk membuat, mengelola, dan berbagi konten dan sumber daya.

\section{E. Kerangka Berpikir}

Berdasarkan observasi di SMK TI Bali Global Singaraja kelas XI TKJ pada mata pelajaran Jaringan Wireless siswa sering mencari materi di internet karena kurang 
lengkap dan terperincinya modul atau sumber belajar yang telah diberikan, dalam proses pembelajaran setelah pemberian materi guru langsung ke praktikum tidak menjelaskan terlebih dahulu materi yang diberikan, dan siswa belum dapat mengerti dengan benar apa yang diajari oleh guru karena lumayan cepat dalam mengajar.

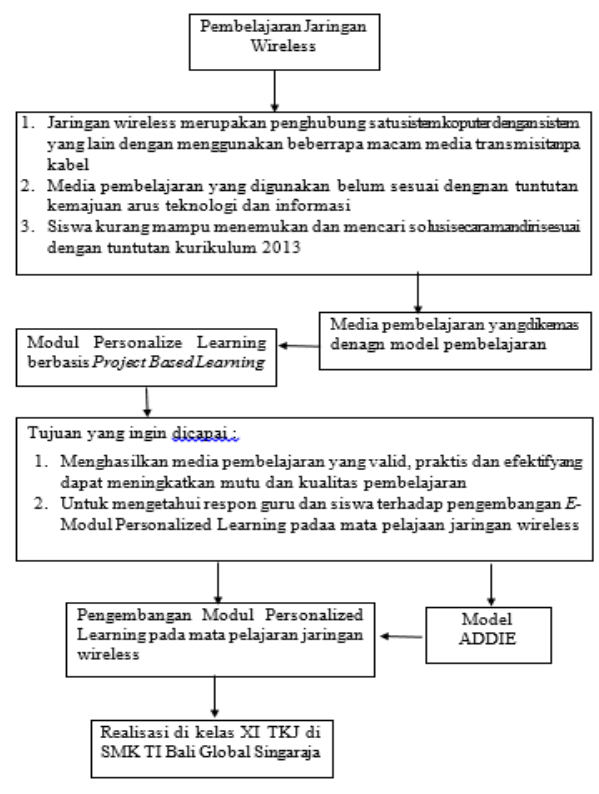

\section{Gambar 1. Kerangka Berpikir} Pengembangan e-modul

\section{METODOLOGI PENELITIAN}

Metode penelitian yang digunakan pada penelitian ini adalah metode R\&D (Research and Development). Metode penelitian dan pengembangan merupakan metode penelitian yang digunakan untuk menghasilkan produk tertentu dan mennguji keefektifan produk tersebut (Sugiyono,2013). Penelitian ini memliki tujuan untuk mengembangkan e-modul di SMK TI Bali Global Singaraja.

Teknik Pengumpulan Data

Data yang dikumpulkan untuk dianalisis bersifat kualitatif dan kuantitatif dalam penelitian ini, yaitu meliputi informasi

sumber belajar, kevalidan e-modul dan respon siswa dan guru terhadap e-modul yang akan dikembangkan. Teknik pengumpulan data dapat dilihat pada Tabel 1.

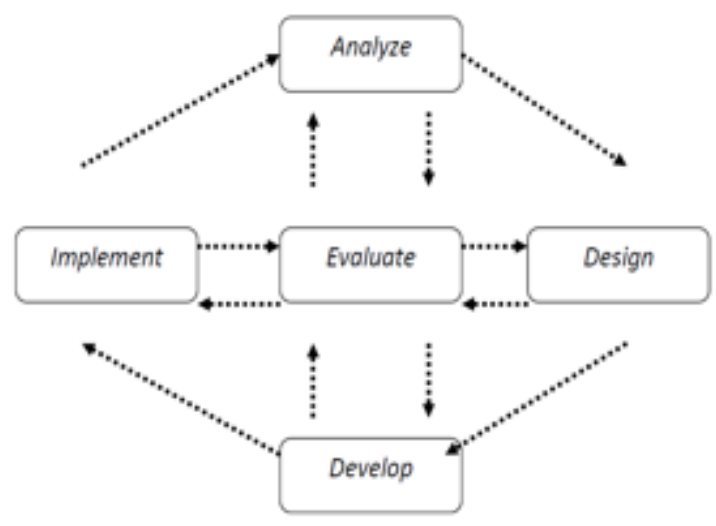

Gambar 2. Alur Fase Pengembangan Model ADDIE (Adiputra, 2014)

Tabel 1. Teknik pengumpulan data

\begin{tabular}{|c|c|c|c|}
\hline No & $\begin{array}{l}\text { Jenis } \\
\text { Data }\end{array}$ & Metode & Sumber Data \\
\hline 1 & $\begin{array}{l}\text { Informasi } \\
\text { tentang } \\
\text { sumber } \\
\text { belajar }\end{array}$ & $\begin{array}{l}\text { Wawanc } \\
\text { ara }\end{array}$ & $\begin{array}{l}\text { Guru Mata } \\
\text { Pelajaran } \\
\text { Jaringan } \\
\text { Wireless }\end{array}$ \\
\hline 2 & $\begin{array}{l}\text { Karakteris } \\
\text { tik } \\
\text { peserta } \\
\text { didik }\end{array}$ & Angket & $\begin{array}{l}\text { Peserta didik } \\
\text { kelas X TKJ } \\
\text { di SMK TI } \\
\text { Bali Global } \\
\text { Singaraja }\end{array}$ \\
\hline 3 & $\begin{array}{l}\text { Kevalidan } \\
\text { e-modul }\end{array}$ & Angket & $\begin{array}{l}\text { Ahli isi } \\
\text { pembelajaran, } \\
\text { ahli desain } \\
\text { pembelajaran, } \\
\text { dan ahli } \\
\text { media } \\
\text { pembelajaran }\end{array}$ \\
\hline 4 & $\begin{array}{l}\text { Respon } \\
\text { guru dan } \\
\text { peserta } \\
\text { didik }\end{array}$ & Angket & $\begin{array}{l}\text { Guru Mata } \\
\text { Pelajaran } \\
\text { Jaringan } \\
\text { Wireless dan } \\
\text { peserta didik } \\
\text { kelas X TKJ } \\
\text { di } \\
\text { SMK TI Bali } \\
\text { Global } \\
\text { Singaraja }\end{array}$ \\
\hline
\end{tabular}


Pada kegiatan observasi guna mendapat informasi sumber belajar dan karakteristik pembelajar, digunakan jenis metode wawancara serta angket tertutup dan terbuka. Melalui metode wawancara dan angket ini peneliti mengetahui masalah yang terjadi ketika pembelajaran berlangsung terkait sumber belajar, materi, media, dan ketertarikan serta karakteristik siswa dalam pembelajaran Jaringan Wireless.

Metode angket digunakan dalam kegiatan review dari ahli isi bidang studi, ahli desain pembelajaran, ahli media pembelajaran, uji coba perorangan, uji coba kelompok kecil, dan uji coba lapangan. Uji para ahli terdiri dari dua pilihan yaitu Sesuai dan Tidak Sesuai, sedangkan untuk uji coba perorangan, uji coba kelompok kecil, uji coba lapangan, dan uji respon terdiri dari lima pilihan, yaitu Sangat Setuju (SS), Setuju (S), Kurang Setuju (KS), Tidak Setuju (TS), dan Sangat Tidak Setuju (STS). Untuk skor pada angket uji coba dapat dilihat pada Tabel 2.

Tabel 2 Metode Reviw Ahli

\begin{tabular}{|l|l|l|}
\hline Alternatif & $\begin{array}{l}\text { Skor } \\
\text { Pernyataan } \\
\text { Positif }\end{array}$ & $\begin{array}{l}\text { Skor } \\
\text { Pernyataan } \\
\text { Negatif }\end{array}$ \\
\hline $\begin{array}{l}\text { Sangat Setuj } \\
\text { (SS) }\end{array}$ & 5 & 1 \\
\hline Setuju (S) & 4 & 2 \\
\hline $\begin{array}{l}\text { Kurang Setuj } \\
\text { u } \\
\text { (KS) }\end{array}$ & 3 & 3 \\
\hline $\begin{array}{l}\text { Tidak Setuju } \\
\text { (TS) }\end{array}$ & 2 & 4 \\
\hline $\begin{array}{l}\text { Sangat } \\
\text { Tidak }\end{array}$ & 1 & 5 \\
Setuju (SKS) & \\
G. TEKNIK ANALISIS DATA \\
Analisis data pada penelitian \\
pengembangan ini bertujuan untuk \\
menjawab rumusan masalah dalam \\
kesimpulan. Berikut ini merupakan teknik
\end{tabular}

analisis data yang digunakan oleh peneliti, diantaranya yaitu :

1. Analisis data kevalidan Modul Ajar Analisis data kevalidan e-modul dimaksudkan untuk mengetahui sejauh mana e-modul yang telah dibuat memenuhi kriteria berdasarkan penilaian validator yang ditunjuk dengan menggunakan lembar validasi ahli, hasil validasi ahli menjadi dasar dan pertimbangan dalam melakukan revisi.

2. Analisis data respon guru dan siswa Analisis data respon guru dan siswa dimaksudkan untuk mengetahui bagaimana respon guru dan siswa terhadap e-modul yang dikembangkan

H. ANALISIS DATA KEVALIDAN E-MODUL Validasi e-modul diuji oleh ahli isi, ahli desain, ahli media, uji perorangan dan uji kelompok kecil, menganalisis respon guru dan siswa terhadap pengembangan emodul diuraikan sebagai berikut.

\section{Evaluasi Validitas}

Setelah melaui tahap pengujian para ahli, didapatkan hasi uji ahli isi dengan hasil perhitungan 0,93 menunjukkan pada kriteria "Sangat Tinggi", hasil uji desain dengan hasil perhitungan 0,73 menunjukkan pada kriteria "Tinggi", dan hasil uji media dengan hasil perhitungan 0,93 menunjukkan pada kriteria "Sangat Tinggi".

\begin{tabular}{|c|c|}
\hline Pengujian Ahli & Hasil Perhitungan \\
\hline Ahli Isi & 0,93 \\
\hline Ahli Desain & 0,73 \\
\hline Ahli Media & 0,93 \\
\hline Rata-rata & 0,86 \\
\hline
\end{tabular}

Rata-rata hasil perhitungan uji validitas mendapatkan hasil 0,86, jika dikonversika ke tabel kriteria rata-rata uji ahli pada Tabel 3.3 menunjukkan pada kriteria "Valid". Dengan hasil perhitungan ini maka dapat 
dikatakan e-modul jaringan wireless Valid dan layak digunakan dalam pembelajaran.

\section{Efektifitas E-Modul}

Setelah melakukan uji lapangan selanjutnya dilakukan uji efektivitas dari emodul. Dalam uji efektivitas peneliti menggunakan hasil dari perhitugan uji lapangan. Hasil penelitian menunjukkan bahwa $84.33 \%$ hasil uji lapangan sebanyak 21 siswa yang memberikan jawaban pada angket menunnjukkan bahwa penggunaan $e$-modul ini telah efektif.

\begin{tabular}{|c|c|}
\hline $\begin{array}{c}\text { Konversi Tingkat } \\
\text { Pencapaian }\end{array}$ & Persentase \\
\hline Sangat Baik & $14,3 \%$ \\
\hline Baik & $76,2 \%$ \\
\hline Cukup & $9,5 \%$ \\
\hline Jumlah & $84,33 \%$ \\
\hline
\end{tabular}

Dari hasil ini menujukkan bahwa e-modul personalized learning efektif untuk di terapkan dalam pembelajaran, degan hasil persentase $84,33 \%$ jika di konvesikan ke dalam tabel kriteria efektivitas e-modul pada Tabel 3.6 menunjukkan pada kriteria "Efektif".

\section{Kepraktisan E-Modul}

Setelah melakukan uji respon siswa, guru dan evaluator, selajutnya dilakukan perhitugan kepraktisan e-modul dengan merata-ratakan hasil perhitungan respon siswa, guru dan evaluator. Hasil dari respon siswa sebesar $60,52 \%$ dengan kriteria positif, hasil dari respon guru sebesar 42 dengan kriteria positif, dan respon evaluator sebesar 43 dnegan kriteria positif.

\begin{tabular}{|c|c|}
\hline Respon & Jumlah Skor Per Responden \\
\hline Guru & 84 \\
\hline siswa & 60,52 \\
\hline Rata-rata & 72,26 \\
\hline
\end{tabular}

Hasil rata-rata respon guru dan evaluator sebesar 85 , selanjutnya dicari rata-rata kepraktisan e-modul. Mendapatkan hasil 72,26 jika dikonversikan dalam table kriteria pada Tabel 3.7 berada pada kriteria "Praktis".

\section{PEMBAHASAN}

Pengembangan e-modul mata pelajaran Jaringan Wireless memiliki tujuan untuk membantu penambahan sumber belajar, media pembelajaran, meningkatkan kemandirian siswa dan diharapkan dapat meningkatkan pemahaman materi pelajaran Jaringan Wireless selama proses belajar yang dilakukan tanpa tatap muka dengan guru. Berdasarkan hasil observasi awal yang dilakukan di SMK TI Bali Global Singarja, Terdapat permasalahan proses pembelajaran terkait cara belajar yang kurang tepat. Permasalahan yang terjadi diantaranya dalam proses pembelejaran setelah pemberian materi guru lagsung ke praktikum dan tidak menjelaskan materi yang telah diberikan. Selain itu siswa belum dapat mengerti dengan benar apa yang diajari oleh guru karena lumayan cepa dalam mengajar, dan permasalahan lain siswa sering mencari materi di internet karena kurang lengakap dan terperincina modul atau sumber beajar yang diberikan. Oleh karena itu dipandang perlu untuk membuatkan media pembelajaran terkait dengan pelaksanaan pembelajaran yang mengharuskan siswa untuk belajar mandiri dengan permasalahan sumber ajar yang ada dengan pengembangan e-modul Personalized Learning. Kelebihan e-modul dibandingkan dengan modul cetak adalah sifatnya yang interaktif memudahkan dalam navigasi, dapat menampilkan atau memuat gambar, audio, video dan animasi serta dilengkapi tes formatif yang memungkinkan umpan balik otomatis dengan segera.

Tahapan ketiga adalah tahap Development Tahapan ini sebagai lanjutan kegiatan pada tahap desain. Pada tahap ini dihasilkan prototipe 1 sebagai realisasi hasil perancangan modul Pada tahap ini dilakukan pengembangan sistem seperti membuat hak akses masuk ke halaman mata pelajaran, mengatur tampilan kegiatan pembelajaran, menerapkan modul cetak ke sistem e-modul, mengintegrasikan fitur Schoology pada e-modul meliputi penerapan hasil modul ke dalam platform schoology hingga menjadi produk akhir 
berupa emodul. Pengembangan pada fitur schoology disesuaikan dengan kerangka modul yang digunakan dan berisikan implementasi tahapan Project Based learning pada e-modul. Selain itu peneliti mengembangkan video pembelajaran pada kegiatan pembelajaran tertentu yang nantinya video pembelajaran tersebut dijadikan sumber belajar bagi siswa.

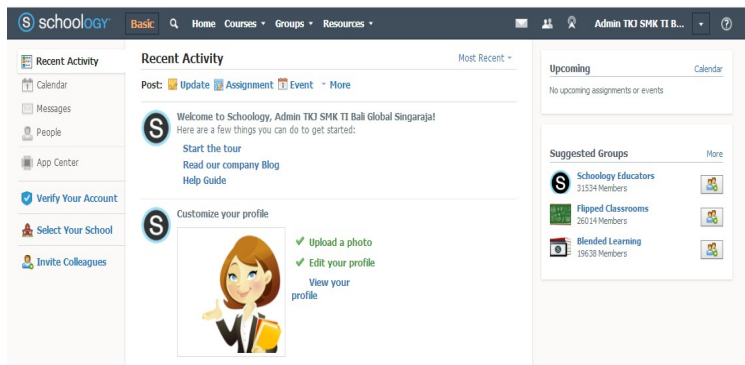

Tahap keempat adalah Implementasi, yang dilakukan dengan menguji coba emodul sesuai dengan peran dan fungsinya dalam proses pembelajaran untuk mengetahui sejauh mana manfaat produk yang dikembangkan. Tahapan uji coba dimulai dari review para ahli, kemudian dilanjutkan dengan uji coba perorangan, kelompok kecil, dan uji lapangan. Uji ahli yang pertama dilakukan adalah uji ahli isi pembelajaran. Uji ahli ini bertujuan untuk mengetahui isi yang terkandung di dalam emodul apakah sudah sesuai dengan konsep pengetahuan atau indikator yang ingin dicapai. Setelah selesai melakukan uji ahli isi, kemudian dilanjutkan dengan uji ahli desain. Uji Ahli desain ini bertujuan untuk mendapatkan validasi e-modul dari segi desain pembelajaran yang terdapat dalam e-modul mata pelajaran Jaringan Wireless. Setelah selesai melakukan uji ahli media pembelajaran kemudian dilanjutkan dengan uji media pembelajaran. Uji media pembelajaran ini bertujuan untuk mendapatkan validasi dari segi tampilan dan struktur modul yang disajikan dalam emodul Jarigan Wireless.

Tahap ke lima adalah Evaluasi. Setelah melaui tahap pengujian para ahli, didapatkan hasi uji ahli isi dengan hasil perhitungan 0,93 menunjukkan pada kriteria "Sangat Tinggi", hasil uji desain dengan hasil perhitungan 0,73 menunjukkan pada kriteria "Tinggi", dan hasil uji media dengan hasil perhitungan 0,93 menunjukkan pada kriteria "Sangat Tinggi". Rata-rata hasil perhitungan uji ahli mendapatkan hasil 0,86 menunjukkan pada kriteria "Valid". Menurut (Sugiono.2010) "Validasi produk dapat dilakukan oleh beberapa pakar atau tenaga ahli yang sudah berpengalaman untuk menilai kelemahan dan kekuatan produk yang dihasilkan". Agar suatu produk dapat digunakan sesuai dengan tujuannya.

Setelah melakukan uji lapangan selanjutnya dilakukan uji efektivitas dari emodul. Dalam uji efektivitas peneliti menggunakan hasil dari perhitugan uji lapangan. Hasil penelitian menunjukkan bahwa $84.33 \%$ hasil uji lapangan sebanyak 21 siswa yang memberikan jawaban pada angket menunnjukkan bahwa penggunaan e-modul ini telah efektif. Dari hasil ini menujukkan bahwa e-modul personalized learning efektif untuk di terapkan dalam pembelajaran, degan hasil persentase $84,33 \%$ jika di konvesikan ke dalam tabel kriteria efektivitas e-modul pada Tabel 3.6 menunjukkan pada kriteria "Efektif". Menurut (Satrio: 2008) Efektivitas merupakan pengaruh atau dampak yang merupakan hasil dari kebijakan atau langkah yang diambil, yang tentunya diambil dari keinginan-keinginan untuk mencapai target dengan melihat kenyataan yang ada di lapangan.

\section{Chart Area Uji Respon Lapangan}

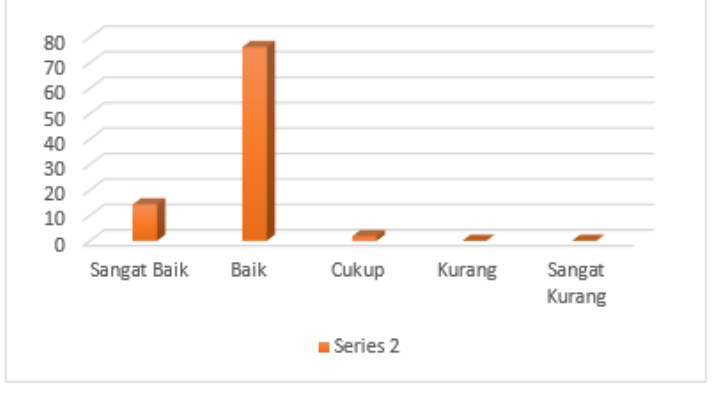




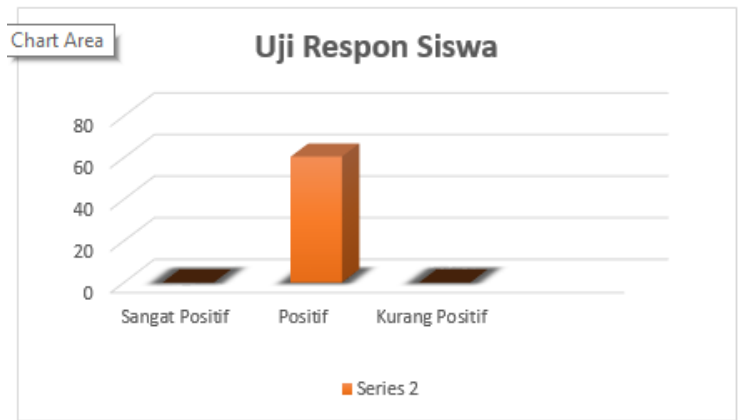

Setelah melakukan uji respon siswa, guru dan evaluator, selajutnya dilakukan perhitugan kepraktisan e-modul dengan merata-ratakan hasil perhitungan respon siswa, guru dan evaluator. Hasil dari respon siswa sebesar $60,52 \%$ dengan kriteria positif, hasil dari respon guru sebesar 42 dengan kriteria positif, dan respon evaluator sebesar 43 dnegan kriteria positif. Hasil rata-rata respon guru dan evaluator sebesar 85 , selanjutnya dicari rata-rata kepraktisan e-modul. Mendapatkan hasil 72,76 jika dikonversikan dalam table kriteria pada Tabel 3.7 berada pada kriteria "Praktis". Menurut (Mudjijo.1995) "Salah satu instumen tersebut dapat dan mudah dilaksanakan serta ditafsirkan hasilnya". Selanjutnya Mudjijo juga berpendapat bahwa kepraktisan menunjukan pada tingkat kemudahan penggunaan dan pelaksanaannya yang meliputi biaya dan waktu dalam pelaksanaan serta pengelolaan dan penafsiran hasilnya. Tujuan uji kepraktisan dilakukan agar mengetahui sejauh mana kemudahan serta keterlaksanaan e-modul yang dibuat.

Hasil penelitian e-modul pada mata pelajaran Jaringan Wireless ini sejalan dengan (Paramita N. P., 2017) yaitu Pengembanngan PENGEMBANGAN EMODUL PEMBELAJARAN ADMINISTRASI SERVER KELAS XI TKJ DI SMK TI BALI GLOBAL SINGARAJA yaitu sama-sama memperoleh penilaian layak dan mendapat respon positif. Hasil penelitian ini juga terkait dengan penelitian (wijayanti2016) tentang Pengembangan e-modul berbasis project based learning pada mata pelajaran simulasi digital untuk siswa kelas $X$ studi kasus di SMK Negeri 2 Singaraja yaitu sama-sama memperoleh penilaian layak pada uji coba perorangan, kelompok kecil, dan lapangan untuk diimplementasikan sebagai media pembelajaran.

Kendala yang dihadapi peneliti yaitu pertama pada pengembangan e-modul peorsonalized learning menggunakan Paltform Schoology yaitu pada pengaturan jenis font yang akan digunakan pada saat pengimputan materi, yang kedua pada waktu pengimplementasian, peneliti hanya mengimplementasikan uji lapangan pada pembelajaran 1 saja.

\section{KESIMPULAN}

Berdasarkan hasil penelitian dan pembahasan pada penelitian Pengembangan Modul Persoankized Learning pada Mata Pelajaran Jaringan Wireless untuk Siswa Kelas XI Teknik Komputer Jaringan di SMK TI Bali Global Singaraja, maka penulis dapat menarik kesimpulan sebagai berikut.

1. Hasil rancangan dan implementasi Pengembangan Modul Personalize Learning pada Mata Pelajaran Jaringan WIreless untuk Siswa Kelas XI Teknik Komputer Jaringan di SMK TI Bali Global Singaraja menggunakan tahapan model project based learning sudah dinyatakan berhasil diterapkan. Hal ini dapat dilihat dari rata-rata persentase kevalidan e-modul berdasarkan hasil pengujian yang telah dilakukan sebesar 0,86. Jika dikonversikan ke dalam tabel konversi menunjukkna "Valid".

2. Respon guru terhadap Pengembangan Modul Personalized Learning pada Mata Pelajaran Jaringan Wireless untuk Siswa Kelas XI Teknik Komputer Jaringan di SMK TI Bali Global Singaraja didapatkan rata-rata sebesar 42. Jika dikonversikan ke dalam tabel kriteria penggolongan respon maka hasilnya termasuk dalam kategori positif. Sedangkan untuk respon siswa terhadap pengembangan e-modul 
administrasi server memperoleh ratarata sebesar 60,52. Jika dikonversikan ke dalam tabel kriteria penggolongan respon maka hasilnya termasuk dalam kategori sangat positif.

\section{SARAN}

Berdasarkan pengamatan penulis, terdapat beberapa hal yang dapat dijadikan bahan pertimbangan untuk ditindak lanjuti.

1. Bagi pengembang e-modul selanjutnya agar dapat mengatur e-modul lebih user friendly atau mudah digunakan oleh pengguna yang masih belum terbiasa dengan pembelajaran berbasis komputer. Selain itu, dapat mengatur agar setiap tahapan pembelajaran Project Based Learning ada fitur yang bisa memberikan tantangan baik berupa games atau bentuk lainnya dan pengembangan untuk pengaturan font pada Schoology bisa dilakukan seperti menggunakan office.

2. Produk e-modul berbasis model pembelajaran project based learning pada mata pelajaran jaringan wireless untuk siswa kelas XI Teknik Komputer Jaringan di SMK TI Bali Global Singaraja yang dikembangkan belum sampai pada tahap pengukuran hasil belajar siswa dan pembelajaran yang di implementasikan pada saat uji Ipangan hanya pada proses pembelajaran 1 saja. Oleh karena itu, perlu diadakan pengkajian lebih lanjut mengenai efektivitas penggunaan e-modul berkaitan dengan pengukuran hasil belajar siswa pada proses pembelajaran 2, 3, 4, dan 5 dengan menggunakan e-modul ini melalui penelitian eksperimen dengan menguunakan konten dan model pembelejaran yang berbeda.

\section{REFERENSI}

Agustini, K. (2013). PENGARUH PENGGUNAAN SIMULASI BINARY TREE BERBASIS CAI. Jurnal Pendidikan Indonesia.
Ariasa, K. (2016). pengembangan e-modul berbantuan CAI pada mata pelajaran fotografi kelas $X$ desain kounikasi visualdi SMK Negeri 1 Sukasada. jurnal nasional pendidikan teknik informatika (JANAPATI), 8.

Dimhad. (2014). Penggunaan E-Modul Interaktif Melalui Pembelajaran Berbasis Masalah Untuk Meningkatkan Pemahaman Konsep Sistem Saraf, Kemampuan Generik Sains Dan Berpikir Kritis. Retrieved Januari 20, 2016, from http://dimhad13.110mb.com/buku6/a .pdf

Herry, H. A. (2007). belajar dan pembelajaran sekolah dasar. Bandung: UPI Press.

Kamdi, W. (2008). Project-Based Learning: Pendekatan Pembelajaran Inovatif. Malang: Universitas Negeri Malang.

Laviatan, T. (2008). InnovativeTeachingand Assessment Method: QBland Project Based Learning. MathematicsEducati, 105-116.

Paramita, N. P. (2017, juli). PENGEMBANGAN E-MODUL PEMBELAJARAN ADMINISTRASI SERVER. Jurnal Nasional Pendidikan Teknik Informatika.

Paramita, N. P. (2017). PENGEMBANGAN E-MODUL PEMBELAJARAN ADMINISTRASI SERVER. Jurnal Nasional Pendidikan Teknik Informatika. 